\title{
The Legality and Propriety of the Trials of Abu Hamza
}

\author{
PAUL ARNELL *
}

\section{Introduction}

The saga of Abu Hamza is a tale of imperfect justice which raises two interesting and important questions. These are whether his trials in the UK and US were lawful under public international law and whether they were proper or appropriate. In an era where an increasing number of states are affected by transnational criminality, and apply their law across borders in response, the rules surrounding criminal jurisdiction in international law have assumed greater importance. The rule of law, comity of nations and human rights of accused persons are amongst the factors that militate in favour of legality and propriety in the operation of transnational criminal justice. Both the existing rules of criminal jurisdiction and an embryonic proper law of the crime approach serve these purposes. The former govern and circumscribe the lawful ability of states to take cognisance of extraterritorial acts. Whilst generous in allocating competency, states are restricted to acting where there is a sufficient link or connection between it and the crime or accused. The breadth of the rules gives rise to concurrent jurisdiction amongst states. It is here that the proper law of the crime approach can be seen to apply. It is designed to ascertain which of the states connected to a crime or accused person can most appropriately apply its law. The proper law approach not only focuses upon the existence of a link between a state and a crime or an accused, but also the nature and relative strength of that link vis-à-vis other states. Note, though, the approach is not yet a part of international law. Whilst there are some authorities supporting it, the discussion of the proper law approach below is de lege ferenda.

* Dr. Paul Arnell, Reader in Law, Law School, Robert Gordon University, Aberdeen, Scotland, p.arnell@rgu.ac.uk. The author wishes to thank the anonymous reviewer for her/his comments and suggestions, any errors and infelicities are my own.

This is an Open-access article distributed under the terms of the Creative Commons Attribution 3.0 Unported License (http://creativecommons.org/licenses/ by/3.0/), permitting all use, distribution, and reproduction in any medium, provided the original work is properly cited. 
The rules governing the legality and propriety of the application of criminal law across borders are tested and illustrated by the case of Abu Hamza. Indeed, it is a notable instance where the UK and US extended their law and took cognisance of Hamza's extraterritorial terrorist-related crimes. It is significant on account of the nature of the crimes he committed, the number of states with a connection to those crimes, and the volume of litigation arising from his acts. Hamza was found guilty of a range of terrorist-offences, including the extraterritorial solicitation to murder, the organisation of a hostage-taking in Yemen and of facilitating jihad in Afghanistan. These offences had an impact in or affected a number of different states. In addition to the UK and the US, Sweden, Australia, Canada, Afghanistan and Yemen were all affected in one way or other. Each of these was arguably entitled under international law to try Hamza. As such, the case is well-suited to expose and analyse the proper law of the crime approach. Aiding analysis generally are the various judicial decisions that litter Hamza's story. Courts in the UK and the US and the European Court of Human Rights (ECtHR) have all been seized with aspects of the case. The extension of UK law to extraterritorial solicitation to murder and the compatibility with human rights law of Hamza's extradition to the US are among the issues decided judicially. The final decision in Hamza's case was that imposing his US sentence. In early 2015 he was sentenced to life in prison in Manhattan Federal Court. After being sentenced US Assistant Attorney General John P. Carlin stated

\begin{abstract}
Abu Hamza is an unrepentant all-purpose terrorist. With today's sentence, he is being held accountable for the many ways in which he supported terrorism and other terrorists through much of his life... This case was charged over ten years ago and was tried after years of extradition proceedings - and is but one example of our resolve to pursue those who threaten the United States and our interests anywhere in the world no matter how long it takes. ${ }^{1}$
\end{abstract}

This statement underlines the need for the rules discussed in this article. Rules of criminal jurisdiction and a proper law of the crime approach exist to both facilitate and limit the criminal jurisdiction of states. Without them the system of transnational justice is amenable to becoming a prosecutorial 'wild-west', where states with the resources and desire may act without legal limit. This article begins by discussing the facts, law and litigation relevant to Hamza's case. It then analyses the legality and propriety of UK and US action. The possible consequences of illegality or impropriety, be they a claim against the UK or US by a third state or otherwise, are not subject to discussion.

1 FBI Press Release 9 January 2015, www.fbi.gov/newyork/press-releases/2015/mustafa-kamelmustafa-a-k-a-abu-hamza-sentenced-in-manhattan-federal-court-to-life-in-prison, (accessed 3 August 2016). 


\section{Facts, Law and Litigation}

\subsection{Abu Hamza}

Abu Hamza, also known as Mustafa Kamel Mustafa, was born in Alexandria, Egypt in 1958. He was the son of a naval officer and a primary school headmistress. ${ }^{2}$ He emigrated to England in 1979 at the age of 21. Hamza studied civil engineering, gaining a degree and becoming a member of the Institution of Civil Engineers. In 1987 Hamza moved to Afghanistan. Around this time he lost both hands and an eye, the precise circumstances of which are unclear. In 1993 Hamza returned to the UK, and became a leading figure in the British Islamic scene. He began preaching at Finsbury Park Mosque in London in 1997 where he was later to assume the role of Imam. Hamza's acts during this period led to investigations and criminal trials in the UK and the US. These began in the UK in 1999 when he was questioned over alleged bomb plots in the Yemen. Prior to being charged, in 2004, Hamza was arrested following a US extradition request. He was later charged in the UK with offences related to his sermons and a terrorism handbook found at his home. The charges had an extraterritorial dimension. He was convicted on eleven counts and jailed for seven years. Whilst in prison he fought his extradition. In 2012, having served his sentence, he was extradited. He was convicted in the US of terrorist-related offences in May 2014.

\subsection{Hamza’s Criminal Acts}

Hamza was present within the UK during the period that the acts that led to his UK and US convictions took place. The acts behind Hamza's UK conviction were public speeches he gave within and outside Finsbury Park Mosque, the possession of recordings of those speeches and the possession of volumes of the Afghani Jihad Encyclopaedia. A number of those speeches were in support of jihad. One such speech, which was recorded, contained the words:

We ask Muslims to do that, to be capable to do that, to be capable to bleed the enemies of Allah anywhere, by any means. You can't do it by nuclear weapon, you do it by the kitchen knife, no other solution. You cannot do it by chemical weapons, you have to do it by mice poison. Like you imagine you have one small knife and you have a big animal in front of you. The size of the knife - you cannot slaughter him with this. You have to stab him here and there until he bleeds to death. Then you can cut up the meat as you like to, or leave it to the maggots. This is the first stage of Jihad. ${ }^{3}$

2 A profile of Hamza is found at www.bbc.co.uk/news/uk-11701269, (accessed 3 August 2016).

3 Cited at www.theguardian.com/uk/2006/feb/07/terrorism.world, (accessed 3 August 2016). 
The possession of a recording of this speech formed the basis of one of the counts to which Hamza was convicted. His possession of copies of ten volumes of the Afghani Jihad Encyclopaedia, described by prosecutors as a terrorism manual and containing information 'of a kind likely to be useful to a person committing or preparing an act of terrorism', formed the basis of the final counts of Hamza's conviction.

Hamza's US criminal liability was based upon three distinct sets of circumstances. The first was a hostage taking in Yemen in December 1998 where 16 tourists were seized. The 16 comprised 11 UK nationals, two Americans, two Australians and a Canadian. Hamza had provided assistance and encouragement from the UK by way of the supply of a satellite phone to a hostage taker and speaking with him during the course of the episode. Following the seizure, the Yemeni military launched a rescue operation during which four hostages were killed and several others wounded. Those killed were three British and one Australian. An American female was injured. ${ }^{4}$ Two of the hostage takers were killed in the rescue and four were arrested by Yemeni authorities. Three were found guilty and sentenced, one to death. The leader of the group, Zein Al-Abidine al-Mihdar, was executed on 18 October $1999 .{ }^{5}$

The second set of circumstances entailed an attempt to create a terrorist training camp in Oregon. Hamza played a part in the plot with Oussama Kassir (a Swedish national), Haroon Aswat (a UK national), and Earnest Ujaama (a US citizen). The relevant events included, in November 1999, the travel of Aswat and Kassir to Oregon, under Hamza's direction, in the possession of a manual on sarin nerve gas and letters of appreciation to Usama bin Laden. Kassir was convicted in the US with conspiring with Hamza in connection with the camp on 12 May 2009. His appeal was rejected. ${ }^{6}$ Aswat was extradited to the US in October 2014, and pled guilty in March 2015.

The third set of facts entailed activities taking place in Afghanistan in 2000 and 2001 categorized as 'facilitating jihad'. Particularly, Hamza asked Ujaama to escort one of his followers, Feroz Abassi (a UK national), from London to a terrorist training camp in Afghanistan, and to meet with Ibn Sheikh al-Libi - suspected by the US of being a high-ranking Al Qaeda official. Abassi had been encouraged to attend the camp whilst at Finsbury Mosque. Later, Ujaama and Abassi went from London to Pakistan, and then, separately, to Afghanistan. In December 2001 the US apprehended Abassi in Afghanistan. He was taken to Guantanamo Bay, in January 2002, and released back to the UK

4 Both American hostages testified in Hamza's US trial, www.nytimes.com/2014/05/08/nyregion/ hostage-testifies-about-post-rescue-meeting-with-imam-charged-in-kidnapping.html?_r=1, (accessed 3 August 2016). One of the two, Mary Quin, has written a book about her experience, Quin, Kidnapped in Yemen: One Woman's Amazing Escape from Terrorist Captivity (Mainstream Publishing 2006).

5 See www.theguardian.com/world/1999/oct/18/yemen, (accessed 3 August 2016).

6 FBI Press Release 15 Sept. 2009, www.fbi.gov/newyork/press-releases/2009/nyfo091509.htm, (accessed 3 August 2016). 
in 2005 (Abassi was paid up to 1 million pounds by the UK Government to settle civil claims in regard to its complicity in his rendition and detention). Ujaama was arrested in 2002. He testified against Hamza as a co-operating witness.

\subsection{The Criminal Law Applied to Hamza}

In the UK Hamza was convicted of eleven counts under the Offences Against the Person Act 1861 (OAPA), the Public Order Act 1986 and the Terrorism Act 2000. Of particular relevance for our present purposes - highlighting the extraterritorial facets of his case - is the offence under the OAPA - soliciting to murder contrary to section 4 . This is because it was applied against Hamza on an extraterritorial basis - the law was extended across the UK border and took cognisance actual or putative effects in one or more third countries. Hamza's conviction of counts of soliciting to murder is also relevant because it was the subject of an appeal. The OAPA does not contain clear and explicit provision on the ambit or range of section 4 . The section inter alia provides ' whosoever shall solicit, encourage, persuade, or endeavour to persuade, or shall propose to any person, to murder any other person, whether he be a subject of Her Majesty or not, and whether he be within the Queen's dominions or not, shall be guilty.... Hamza's convictions under the Public Order Act 1986 and the Terrorism Act 2000 were on a territorial basis - the relevant acts or circumstances took place completely within the UK. ${ }^{7}$

In the US Hamza was convicted of eleven counts. All were extraterritorial. Hamza was never present in the country in the course of their commission. The offences were conspiracy to take hostages and hostage taking (under 18 United States Code section 1203 (abbreviated as 18 USC $\$ 1203)$ ), conspiracy to provide material support to terrorists and conspiracy to provide goods and services to the Taliban (18 USC $₫ 371$ ), two counts of providing material support to terrorists (18 USC $\$ \$ 2339 \mathrm{~A}, 2$ ), two counts of conspiracy to provide material support to a foreign terrorist organisation (al Qaeda) (18 USC $\$$ 2339B), two counts of providing material support to a foreign terrorist organisation (al Qaeda) (18 USC $\$ \$ 2339 \mathrm{~B}, 2)$, and conspiracy to provide material support to terrorists (18 USC $₫ 2339$ A). Jurisdictionally relevant is 18 USC $\$ 1203$, which inter alia provides:

... whoever, whether inside or outside the United States, seizes or detains and threatens to kill, to injure, or to continue to detain another person in order to compel a third person or a governmental organization to do or abstain from doing any act as an explicit or

7 Of note extraterritorially under the UK Terrorism Act 2000 is section 63C, the only instance of UK jurisdiction turning upon the nationality or residence of the victim of a crime (passive personality jurisdiction) and sections 59-61, criminalising the incitement of terrorism abroad. Hamza was not charged with this latter offence, presumably on account of his acts not meeting the criteria of the offence, at least readily. 
Bergen Journal of Criminal Law and Criminal Justice • 2/2016

implicit condition for the release of the person detained, or attempts or conspires to do so, shall be punished by imprisonment for any term of years or for life and, if the death of any person results, shall be punished by death or life imprisonment.

(b) (1) It is not an offense under this section if the conduct required for the offense occurred outside the United States unless-

(A) the offender or the person seized or detained is a national of the United States;

(B) the offender is found in the United States; or

(C) the governmental organization sought to be compelled is the Government of the United States. ${ }^{8}$

Also relevant is 18 USC $\$ 2339 \mathrm{~B}$, which inter alia provides 'Whoever knowingly provides material support or resources to a foreign terrorist organization, or attempts or conspires to do so, shall be fined under this title or imprisoned.... In regard to the ambit of the offence the section provides that it extends to where the accused is a national or habitual resident of the US, he is brought into the US or found within it, the offence occurs in or affects interstate or foreign commerce, and to where an accused aids or abets any person to which it applies.

\subsection{Hamza Litigation}

Hamza's acts spawned ten separate cases or hearings occurring over nearly a decade. These concerned the criminal law, extradition law and human rights law. ${ }^{9}$ Five of these took place within the UK, three at the ECtHR and two in the US. The five UK cases are his criminal trial (7 February 2006, Central Criminal Court), an appeal against this conviction (28 November 2006, Court of Appeal) ${ }^{10}$ two challenges to his extradition at the

8 This provision gives effect to the International Convention Against the Taking of Hostages 1979, UNTS Vol. 1316, p. 205, cited at treaties.un.org/pages/ViewDetails.aspx?src=TREATY\&mtdsg no $=$ XVIII-5\&chapter $=18 \&$ lang=en, (accessed 3 August 2016). Hereinafter the Hostages Convention. The Convention is discussed below.

9 Also resultant from his acts are a Charity Commission Report into North London Central Mosque Trust, published 1 July 2003, and a controversy arising from a BBC report detailing the Queen's communication with the then Home Secretary about Hamza. The former resulted in Hamza's removal by the Charity Commission from his position with the charity under section 18(2) (i) of the Charities Act 1993. The latter ended with a BBC apology to the Queen for disclosing the details of a private conversation, see www.bbc.co.uk/news/uk-19716941, (accessed 3 August 2016).

10 [2006] England and Wales Court of Appeal (EWCA) 2918 Crim. Hereinafter R v Hamza. 
English High Court (20 June 2008 and 5 October 2012) ${ }^{11}$ and an appeal of a decision to strip Hamza of his UK nationality. ${ }^{12}$ At the ECtHR were a challenge to his English conviction (13 July 2007), ${ }^{13}$ an admissibility hearing (6 July 2010) ${ }^{14}$ and a substantive case pertaining to his extradition (10 April 2012). ${ }^{15}$ Within the US there were his criminal trial (19 May 2014, Manhattan Federal Court) and his sentencing hearing (9 January 2015, Manhattan Federal Court).

Each of Hamza's cases contribute to his story. They are relevant presently because they address extraterritorial jurisdiction, extradition and/or human rights. The cases exemplify and substantiate the web of extraterritoriality arising in instances of modern transnational criminality. The web began with his transnational acts and was followed with the extraterritorial application of UK and US criminal law to them. Subsequently, the law of extradition came into play which included an extraterritorial human rights assessment of US policy and practice. Finally, there came Hamza's rendition, trial and sentence. These cases necessarily took considerable time, with fourteen years elapsing between Hamza's acts and the imposition of his US sentence. For our present purposes two of the ten cases or hearings merit discussion. These are Hamza's appeal against his UK conviction, $R$ $v$ Hamza, and the substantive case before the ECtHR in opposition to his extradition, Ahmad $v$ UK. The cases require discussion because they consider issues directly related to the questions of the legality and the propriety of the application of UK and US law to Hamza and his acts.

\subsubsection{Rv Hamza}

Hamza was convicted at the Old Bailey by a judge and jury in early 2006 of offences including soliciting to murder. He was sentenced to seven years in prison. $R v$ Hamza is his appeal against his conviction. The final of the six grounds put forward by Hamza is most germane jurisdictionally. It was an argument that the crime of soliciting to murder abroad under section 4 of the OAPA did not cover the incitement of non-UK nation-

11 Mustafa Kamel Mustafa (Otherwise Abu Hamza) v The Government of the United States of America, Secretary of State for the Home Department (SSHD) [2008] England and Wales High Court (EWHC) 1357 (Admin) and Hamza v Secretary of State for the Home Department, [2012] EWHC 2736 (Admin).

12 See Abu Hamza v SSHD [2010] United Kingdom Special Immigration Appeals Commission (UKSIAC) 23/2003 (05 November 2010), cited at www.refworld.org/docid/4ce2a8022.html, (accessed 3 August 2016).

13 Mustafa (Abu Hamza) (No.1) v United Kingdom, (2011) 52 European Human Rights Reports (EHRR) SE11.

14 Babar Ahmad v UK (2010) 51 EHRR SE6.

15 Ahmad v UK (2013) 56 EHRR 1. Hereinafter Ahmad v UK. 
als. The legal question was whether the crime of soliciting to murder under the OAPA applied on an extraterritorial basis only where the solicitation was of a British national. Hamza's counsel suggested that this was the case. The argument put forward was that it was settled law that the inchoate offences of incitement and conspiracy can only be committed if the activities that are incited or planned will themselves constitute a crime. Since murder abroad by a non-national is not a crime the solicitation of a non-national cannot be unlawful.

The court rejected Hamza's appeal. It was held that section 4 created inchoate offences in relation to murder that were an exception to the general common law position that the acts incited, solicited and conspired must be criminal themselves. The court stated that the rationale for the enactment of section 4 '... appears to have been the activities of aliens in England in support of murders, or attempts to murder, committed by aliens outside the jurisdiction'. ${ }^{16}$ If this was indeed the case, the judgement explained, it made no sense to restrict the offence to situations where the murderers must be British subjects. The wording of the section itself and the comity of nations were also held to support that conclusion. In regard to the latter the court held that it 'would savour of chauvinism'17 if the law were to distinguish between the intended murderer on the basis of nationality. The Court concluded '... everything points to giving the words of section 4 of the 1861 Act the broad meaning that they naturally bear, other than an argument based upon a principle of law which was not clearly established in 1861 and which made no sense if applied to the crime of murder, having regard to the unique extra-territorial jurisdiction long established in relation to that crime.' ${ }^{18}$

\subsubsection{Ahmad v United Kingdom}

Ahmad $v$ United Kingdom is a conjoined judgement of the cases of six applicants heard by the ECtHR. The applicants were Abu Hamza, Babar Ahmad, Haroon Rashid Aswat, Syed Tahla Ahsan, Adel Abdul Bary and Khaled Al-Fawaz. ${ }^{19}$ The extradition of all six was sought by the US on various terrorist-related charges. The extradition requests were accompanied by assurances stipulating that the death penalty would not be sought or carried out, that the trials of the applicants would be before a federal court and that

$16 \quad$ See $\mathrm{R} v \mathrm{Hamza}$ at para. 38.

17 Citing Lord Diplock in R v Treacy 1971 Appeal Cases (AC) 537, at p. 562.

$18 \quad$ See $R v$ Hamza at para. 42.

19 Ahmad $v$ UK held that the case of the third applicant, Aswat, should be considered separately. On 16 April 2013 the ECtHR held that his extradition would entail a breach of article 3 on account of the severity of his mental illness. See further Arnell, The European Human Rights Influence upon United Kingdom Extradition - Myth Debunked, 21 European Journal of Crime, Criminal Law and Criminal Justice (2013) pp. 317-337, at 317. 
none of the accused would be designated enemy combatants. Largely similar arguments against extradition were put forward by each applicant. These were that, the assurances notwithstanding, the risk of capital punishment, designation as enemy combatant and extraordinary rendition remained, and that the possible sentences and 'special administrative measures' they faced whilst in federal prison violated their human rights under the European Convention on Human Rights (ECHR). ${ }^{20}$

The ECtHR reduced the arguments put forward by the applicants to two. They concerned the conditions of their detention and the possible sentences they faced. Both arguments entailed the scrutiny of US practice and law against ECHR standards and as such an extraterritorial application of human rights law. Prior to addressing the arguments the ECtHR discussed two preliminary points. The first is relevant to the propriety of the application of the law in that it concerned the possibility of a UK prosecution. ${ }^{21}$ This arose because the applicants averred that the UK was the appropriate place for their prosecution. They argued that they had stronger links with the UK - personally and in light of their alleged crimes - than the US. ${ }^{22}$ The UK Government replied that domestic proceedings were not underway and the applicants could not be tried for the 'full range and gravamen' of their alleged conduct within the country. ${ }^{23}$ The ECtHR agreed and held that in light of the lack of any intention to prosecute within the UK the question of the appropriate forum did not arise.

The first substantive issue the ECtHR addressed were the conditions at the prison where the applicants would be held if convicted, the Administrative-Maximum US Penitentiary, Florence, Colorado (ADX Florence). It stated '... account has to be taken of the cumulative effects of [the] conditions, as well as of specific allegations made by the applicant. The length of the period during which a person is detained in the particular conditions also has to be considered. ${ }^{24}$ The ECtHR then specifically addressed solitary confinement, recreation and outside exercise, in addition to detention and mental health. Solitary confinement, it held, was not per se in violation of article 3, and would be compatible with it in certain circumstances if accompanied by procedural safeguards. ${ }^{25}$ Recreation and outdoor exercise was held to merit special attention as to its availability, duration and attendant conditions. In regard to mental health, the ECtHR noted that the detention of

20 The special administrative measures, it was argued, could include solitary confinement and the restriction of communications with legal representatives.

21 The second preliminary point addressed the universality or relativity of the prohibition of torture.

22 Whilst discussed below, it can be noted here that subsequent to Hamza's case UK extradition law has been amended to include a 'forum bar' by way of section 50 and schedule 20 of the Crimes and Courts Act 2013. It allows somewhat similar arguments to be made.

23 See Ahmad $v U K$ at para. 163.

$24 \quad$ Ibid at para. 203 (footnotes omitted).

$25 \quad$ Ibid at paras. 205-212. 
persons who are ill may raise issues under article 3, and that the provision of appropriate medical care is necessary. Overall, the ECtHR held the conditions at ADX Florence did not per se violate article 3 . Although the conditions were highly restrictive they did not amount to complete sensory isolation.

The possible prison sentences facing the applicants was the second substantive issue considered by the ECtHR. The Court acted under the assumption that maximum possible sentences would be handed down if the applicants were convicted. These were discretionary life sentences for all bar one. The ECtHR held that that sentence was not grossly disproportionate in light of the terrorist-related charges the applicants faced. The prospective nature of imprisonment made unanswerable the question of whether a legitimate penological purpose was being served at a future date. Such a decision could only be made upon an assessment at a point during the sentence, not years before when it had not yet commenced. However, it was clear, the ECtHR held, that the possible sentences that the applicants save one faced were reducible. The first, third, fourth and sixth applicant, therefore, had not demonstrated a real risk of treatment reaching the threshold of article 3 - including Hamza. The fifth applicant, Adel Abdul Bary, was considered separately because he faced a greater possible punishment, that being multiple sentences of life imprisonment without the possibility of parole. Notably, it was held that barring exceptional circumstances even this sentence was not grossly disproportionate. The extradition of the applicants would not engender a violation of article $3 .{ }^{26}$

\section{Analysis - Lawful and Proper?}

Abu Hamza's story raises important, interesting and controversial questions. Pre-eminent amongst these are whether the application of UK and US criminal law to his extraterritorial acts was lawful under public international law and whether that application was proper or appropriate given the circumstances of his case (the propriety of the application of law per se is discussed below).

\subsection{The Legality under International Law of Hamza's UK and US Trials}

In order to adjudge the legality under public international law of the application of UK and US criminal law to Hamza it is necessary to iterate the germane rules. ${ }^{27}$ The starting

26 Ten further complaints raised by the fifth and sixth applicants were also rejected.

27 There is a copious literature on the subject, including Ryngaert, Jurisdiction in International Law, Second Edition (Oxford University Press 2015), Arnell, Criminal Jurisdiction in International Law, Juridical Review (2000) pp. 179-189, at 179, and Akehurst, Jurisdiction in International Law, 43 British Yearbook of International Law (1972-73) pp. 145-257, at 145. 
point is that international law ascribes to states the lawful ability to exercise authority within and exceptionally outside their territory. Article 1 (b) of the The Harvard Draft Convention on Jurisdiction with Respect to Crime provides 'A State's "jurisdiction" is its competence under international law to prosecute and punish for crime.28 This competence or authority is a consequence, indeed the essence, of sovereignty. It takes different forms. Brownlie identifies two forms or types of competence, prescriptive and enforcement: 'Distinct from the power to make decisions or rules (the prescriptive or legislative jurisdiction) is the power to take executive action in pursuance of or consequent on the making of decisions or rules (the enforcement or prerogative jurisdiction). ${ }^{29}$ What we are concerned with presently is the exercise of authority outside a state's territory because it may be unlawful (and/or improper). Of course international law has come to accept that in certain circumstances states may extend the applicability of their law extraterritorially. The applicable rules are found in customary international law. ${ }^{30}$ There is not a general convention addressing, allocating and/or delimiting criminal jurisdiction in international law. ${ }^{31}$ There are, of course, numerous specific conventions relating to particular inimical acts that contain jurisdictional provisions. Indeed, one such treaty is of direct applicability to Hamza's case - the Hostages Convention. ${ }^{32}$ The rules of customary international law are the product of state practice largely in the form of agreed treaty provisions on the subject, municipal legislation, judicial decisions and executive acts. There is also relevant jurisprudence from international courts and tribunals, including the Case of the SS Lotus (France v Turkey). ${ }^{33}$ The essence of the law is that states are permitted to apply their law extraterritorially in the presence of a connection between it and the accused or crime that falls under an accepted base or principle of jurisdiction.

There are five historical and relatively settled bases of jurisdiction. These are the territorial, active personality (nationality), passive personality, protective and universal. In recent years additional bases have come to be included, such as vicarious or representational base and the effects doctrine. The analysis below will largely rely upon the original five bases because these more novel bases do not apply to the circumstances in Hamza's case. The territorial base is axiomatic - it permits states to apply law to persons, transactions and acts occurring within (or affecting) their territory. Active personality allows

(1935) 29 AJIL (Supp) 439. The Draft Convention is an early academically authoritative development in the area.

$29 \quad$ Brownlie, Principles of Public International Law, $4^{\text {th }}$ ed. (Clarendon Press 1991) p. 298.

30 In Rivard v. United States the United States Court of Appeals, Fifth Circuit, stated 'The law of nations permits the exercise of jurisdiction by nations under five general principles', (1967) 375 Federal Reporter Second Series (F. 2d) 882 at p. 885.

31 There is a Draft Convention on Conflicts of Criminal Jurisdiction, however. It is discussed below.

32 Supra note 8.

33 P.C.I.J. Series A, No. 10, 1927. The position of the Lotus Case is today controversial, with it being thought that the ratio decidendi of the case being bad law. 
states to apply their law to persons in a certain relationship with it - most commonly nationals and residents - wherever they act. Historically controversial, passive personality permits states to apply law to individuals who have committed acts against its nationals. The protective base supports cognizance being taken of acts which are accepted as threatening vital interests of states, such as currency counterfeiting. Finally, the universal base allows states to apply their law to certain acts with reference to the nature of the act alone - with maritime piracy being the most common and historical example. Two related points must be made about the law of international criminal jurisdiction. The first is that it is very generous in allocating competencies. Cumulatively the circumstances legitimised by the various bases of jurisdiction are wide indeed. The second point is that the law very readily admits instances of concurrent jurisdiction. The breadth of the bases of jurisdiction often leads to more than one state being lawfully entitled to apply its law. Further, the circumstances inherent in transnational criminality necessarily give rise to concurrent jurisdiction because it entails the territory, nationality, vital interests etcetera of two or more states. That noted, international law does not contain rules that address concurrent criminal jurisdiction..$^{34}$ Instead the law gives freedom to the custodial state to act or not - in the absence of an extradition request or a conventional prosecute or extradite obligation.

Adjudging the legality of the application of UK law to Hamza and his acts under the rules of criminal jurisdiction is straightforward. The conclusion reached is that the application of UK law was lawful. Whilst one of the points on appeal facing the Court of Appeal was whether English criminal law extended to certain circumstances outside its territorial boundaries UK law was in fact applied on a territorial basis. Hamza was in London when he made the speeches that were deemed to solicit murder and so fall foul of section 4 of the OAPA. The inchoate offence was complete when the solicitation took place, therefore the crime was one that occurred on a territorial basis. This type of crime is not uncommon in UK law. There are several legislative enactments that act in a broadly similar way, including section 1A of the Criminal Law Act 1977, as amended. In general terms this provision criminalises conspiracies entered into in England with a view to the commission of an offence abroad. A leading precedent in UK law in the area is Somchai Liangsiriprasert, Appellant and Government of the United States of America and Another. ${ }^{35} \mathrm{~A}$ different form of territoriality would have come into play if a murder abroad had taken place and Hamza was charged as an accessory to it. Here the form of jurisdiction exercised, in the parlance of international law, would have been subjective territoriality. This exists where an offence begins within a state's territory but is completed outside it. Interestingly, it appears that in such a case under English criminal law an offence would

34 A proper law of the crime approach does exactly that - discussed below.

35 [1991] 1 AC 225. 
only be committed where the murder was committed by one owing allegiance to Her Majesty (in what can be seen as a historic form of nationality jurisdiction).

An analysis of the application of US criminal law to Hamza under public international law is more complex than it was in regard to the UK. This is because Hamza was not present within the US during the commission of the germane acts - there was no direct and tangible territorial connection between Hamza and the US. Of further relevance is Hamza's nationality (not a US citizen) and the fact that certain of the crimes he was accused of being involved with took place in third countries. As seen above, US Federal criminal law was applied to Hamza in respect of three sets of circumstances, a hostage taking in Yemen, moves towards creating a terrorist training camp in Oregon and the facilitation of jihad in Afghanistan. Each set of circumstances necessitates reference to a different base of jurisdiction or a combination of bases.

Hamza's involvement in the Yemeni hostage taking was one of preparation, assistance and direction. His warning to persons not to travel to Yemen prior to the attack supports the fact that he was aware of its imminence. It appears clear that he supplied a satellite telephone to the leader of the hostage takers and spoke to him on the day. ${ }^{36}$ Notably Hamza's stepson, amongst others, had been arrested five days prior to the hostage taking. During the event the hostages were told that they were taken prisoner in order to free the hostage-takers' friends. Governing the application by the US of its law to the hostage taking internationally is the International Convention Against the Taking of Hostages 1979. The US, Yemen and the UK were all parties to the Convention at the appropriate time. The treaty sets out rules applying to the situation. In criminalising hostage taking the US was acting upon its obligations under the treaty. The definition of the offence in US law is based upon its treaty definition. ${ }^{37}$ Article 1(1) defines hostage taking for the purposes of the Convention, and article 1(2)(b) provides that anyone who participates as an accomplice of anyone who commits an act of hostage taking commits an offence for the purposes of the Convention. This would appear to cover the acts of Hamza - the question then being whether the US was lawfully able to extend its law to his acts.

The Convention contains within it articles addressing jurisdiction, prosecution and extradition. ${ }^{38}$ Article 5 of the Convention obliges state parties to establish jurisdiction inter alia where certain offences are committed in order to compel that state to do or abstain from doing any act, and with respect to a hostage who is a national of that state if that state considers it appropriate. Accordingly, the US was not only entitled under international law to extend its law to hostage taking in certain circumstances, but obliged to do so where the hostage takers had made, or were planning to make, demands of the US.

$36 \quad$ FBI press release 9 January 2015, supra note 1.

37 The Notes to the relevant section of the US Code specifically refer to the treaty.

38 It also includes an obligation on the state where an alleged hostage taker is found to either prosecute or extradite the individual, under article 8. 
In that regard it is not clear whether the hostage-taking was undertaken in an attempt to compel the US to act in any way, for example by exerting influence on the Yemeni authorities. Regardless, the Convention permits parties to extend their law on the passive personality basis, and the US had done so. As noted, two of the hostages were US nationals. Overall, then, it seems clear that under the Convention the US was legally entitled to try Hamza for the hostage taking in the Yemen.

Applying customary international law to the application of US law to the hostage taking leads to a similar conclusion. ${ }^{39}$ This is in a sense obvious. The rules of customary international law have developed through state practice, including the collective practice of negotiating, agreeing and implementing treaties. Conventional rules on jurisdiction and those in customary international law are in almost all cases bound to be akin. Here, as noted, the passive personality basis of jurisdiction substantiates the legality of US actions. The protective basis of jurisdiction may also do so. Taking nationals of a state hostage may not unreasonably fall under it - certainly where demands may be made of that state. In any event, the passive personality base of jurisdiction is sufficient to render lawful the US assumption of jurisdiction. The provision within US law criminalising hostage taking extends only where those taken hostage are US nationals, the accused is found within the US or the US Government is the organization the hostage takers are attempting to compel to act or not act. The law and subsequent prosecution appear to clearly fall within the acceptable range of jurisdictional competence in general public international law.

The attempt to set up a terrorist training camp in Oregon is obviously factually very different from the hostage taking in Yemen. It is also jurisdictionally distinct. Hamza was convicted of conspiring with three others in relation to the camp, two of whom are named as having travelled to the US in pursuance of the plan to create a camp that would, inter alia, provide weapons training. ${ }^{40}$ Therefore, to the extent that Hamza's co-conspirators acted within the US there is an unequivocal territorial connection in their cases. Hamza's participation was extraterritorial. The extent of his involvement can be gleaned from the FBI press release issued upon Hamza being sentenced. It states that Hamza directed the two individuals to travel to Oregon, suggesting he was a lead figure in the plan. The crimes Hamza was convicted of in relation to the camp are in line with this. They are conspiracy to provide material support to terrorists and providing material support to terrorists.

The application of US law to Hamza's Oregon-related acts appears to be lawful under international law. There was a definite territorial connection in the case as acts were carried out on US territory by persons apparently directed by Hamza. Upon the assumption

39 This is not to suggest that rules of customary international law may 'trump' a treaty provision on a similar matter, rather to demonstrate that both sources of international law lead to the same result.

$40 \quad$ FBI Press Release, 9 January 2015, supra note 1. 
that Hamza did indeed conspire with the two individuals then the objective territorial basis operates to support the legality of US actions in that a consequence or effect of the conspiracy was felt within US territory. Further, the creation of a terrorist training facility within US territory appears to fall under the protective basis of jurisdiction. Material US national interests were undoubtedly affected by the acts. Interestingly, one of the relevant provisions in US law, 18 USC 2339A, does not contain explicit extraterritorial provision. It has been suggested that the provision is likely to apply '... when an offender or victim is a U.S. national; the offense has an impact in the United States; the offense is committed against U.S. national interests; or the offense is universally condemned..$^{41}$ In light of the objective territorial basis of jurisdiction applying, the presence of additional bases of jurisdiction are not required to substantiate the legality of US actions under customary international law.

The application of US criminal law to the third factual situation giving rise to charges against Hamza, that of facilitating jihad in Afghanistan, is the most difficult to justify under international law. Here, Hamza was convicted of crimes including conspiracy to provide, and providing, material support to al Qaeda and terrorists generally, and conspiracy to provide goods and services to the Taliban. As with the two other sets of circumstances Hamza was in the UK during the material period. The acts giving rise to his criminal activity, according to the FBI, included Hamza requesting persons to travel to Pakistan and Afghanistan and to meet with individuals associated with al Qaeda and the Taliban, and to attend an al Qaeda training camp. ${ }^{42}$ In light of these facts an explicit link between Hamza's acts and the US underpinning one or more of the bases of jurisdiction appears tenuous. There was no territorial link between the acts and the US and there were no US victims of the offences. Harm or potential harm to US vital state interests resulting from the acts is questionable in light of the circumstances commonly suggested as coming under the auspices of the protective base of jurisdiction. It is debatable to argue that crimes of facilitating jihad and/or terrorism fall under the universal basis of jurisdiction. Those crimes appear to fail to attract sufficient support from states to establish that position in customary international law, partly because of the failure of the international community to agree on a definition of terrorism.

One argument in support of the legality of the application of US law is that one of the persons Hamza asked to travel was a US national, Earnest James Ujaama. Hamza, therefore, can be said to be complicit in Ujaama's acts. This supports US jurisdiction on a (vicarious) nationality basis. A further possibility is that US personnel and assets within Afghanistan were reasonably considered under threat from attack by al Qaeda and Tali-

41 Doyle, Terrorist Material Support: An Overview of 18 U.S.C. 2339A and 2339B, Congressional Research Service, 19 July 2010, at p. 21, cited at www.fas.org/sgp/crs/natsec/R41333.pdf, (accessed 3 August 2016).

42 $\quad$ FBI press release, 9 January 2015, supra note 1. 
ban forces. If this is accepted then the US could be seen to be justified in prosecuting the offences on the basis of the protective principle. Of some relevance here are the Congressional Findings to 18 USC $\$ 2339 \mathrm{~B}$ - one of the sections applied to Hamza in regard to the Afghanistan charges. They inter alia provide

... international terrorism is a serious and deadly problem that threatens the vital interests of the United States... the Constitution confers upon Congress the power to punish crimes against the law of nations... and therefore Congress may by law impose penalties relating to the provision of material support to foreign organizations engaged in terrorist activity. ${ }^{43}$

This appears to support the contention that Congress accepts that the prosecution of acts of terrorism is justified with reference to the protective basis of jurisdiction without the US being targeted. ${ }^{44}$ That noted, the relatively tenuous nature of the links between the US and Hamza and his acts in this regard must lead to the conclusion that its application of law to this third circumstance is of dubious legality.

\subsection{The Propriety of Hamza's Trials}

The propriety of the application of UK and US law to Hamza is the second question to be addressed in this article. It is related to, but distinct from, legality. An application of law in a particular case may be lawful - on account of the generosity of the rules in allocating jurisdiction - yet it may be inappropriate. It is distinct because it takes into consideration a wider range of factors. 'Propriety' here denotes appropriateness or legitimacy in the application of criminal law. A proper law approach facilitates a determination of which law is most appropriately applied to a particular set of circumstances. It is predicated upon the assumption that a person, transaction, circumstance or crime may properly be subjected to one body of law and that other bodies of law are either inappropriately or, at best, less appropriately applied. It has its roots in, and is analogous to, 'proper law' or 'choice of law' approaches in various areas of private international law, the most notable

43 United States Code, cited at www.law.cornell.edu/uscode/text/18/2339B, (accessed 3 August 2016).

44 The Findings also mention '... crimes against the law of nations', suggesting that Congress is of the view that terrorism is amenable to universal jurisdiction. As noted, this view is not tenable due to the lack of sufficient consistent and concise state practice defining and prosecuting terrorism on that basis. 
being contract and tort. ${ }^{45}$ It must be noted at the outset, though, that neither international nor municipal law presently contain settled rules governing a proper law crime approach. The following discussion of the application of the proper law approach is, therefore, de lege ferenda. There is not a complete set of rules governing the allocation of criminal jurisdiction as between states that both permits and importantly circumscribes their jurisdiction. Ideally there would be such as system, taking the form of a multi-lateral treaty, obliging state parties to introduce a proper law of the crime approach that would do just that. ${ }^{46}$ This is not likely as states consider the power based in a largely unfettered criminal law as too important a facet of state sovereignty and a tool to protect their national interests. That noted, signs of the emergence of a proper law of the crime approach can be found in various places, including international and national agreements, guidelines on criminal (mainly prosecutorial) co-operation, UK extradition law and a draft convention. ${ }^{47}$ The analysis below is founded upon these authorities and analogous rules.

A proper law system is, simply, a mechanism that attempts to denote the most appropriate legal system. ${ }^{48}$ John Morris has defined it as '... the law which, on policy grounds, seems to have the most significant connection with the chain of acts and consequences in the particular situation before us. ${ }^{49}$ The approach, he said, involves problems being broken down in order to facilitate an adequate analysis of the social factors involved. ${ }^{50}$ Whilst these definitions refer to the concept in a private law sense, a similar exercise can (and should) be applicable to transnational crime. An important difference between adjudging legality and propriety is that the latter entails consideration of factors additional to the

45 See Mann, The Proper Law in the Conflict of Laws, 36 International and Comparative Law Quarterly (1987) pp. 437-453, at 437. A proper law of the crime approach differs in one fundamental respect from that in private international law. In private international law a distinction is drawn between the applicable law and the jurisdiction (state or territory) in which it is to be applied. In criminal law this is not done. States generally do not apply the criminal law of other states. In regard to the criminal law, jurisdiction (state or territory) and the applicable law are inseparable. The proper law of the crime approach governs both the law to be applied and the state which applies it.

46 Perhaps the best way to accomplish this is by way of the introduction of a criminal forum non conveniens cause of action based in a multilateral convention. See Arnell, The Proper Law of the Crime in International Law Revisited, 9(1) Nottingham Law Journal (2000) pp. 39-52, at 39.

47 Other fields of law also provide useful insight into how the concept could develop. In competition law the concept of comity has assumed relevance. It has been defined as '... a voluntary policy calling for a country to give full and sympathetic consideration to other countries' important interests while it is making decisions concerning the enforcement of its own competition laws', OECD Reports, CLP Report on Positive Comity, DAFFE/CLP(99)19, 1999, at para. 18, cited at www.oecd.org/daf/competition/prosecutionandlawenforcement/2752161.pdf, (accessed 3 August 2016).

$48 \quad$ Mann 1987 at p. 438.

49 Morris, The Proper Law of the Tort, 64 Harvard Law Review (1951) pp. 881-895, at 888.

50 Ibid. 
link between the crime, criminal and the state exercising jurisdiction. It is an objective exercise, not a state-specific subjective one. A proper law approach identifies the state or territory which has the most substantial connection to the crime and accused and where the interests of justice are best served by a trial taking place within it.

The rationale behind the desirability of a proper law approach is usefully set out prior to examining the propriety of the application of UK and US law to Hamza. There are three related arguments in favour of a proper law approach. The first is simply that the volume of cases of concurrent criminal jurisdiction is considerable, growing, and may give rise to disputes between states. It is not unusual for a single criminal act to give rise to criminal liability in multiple territories - indeed Hamza's case is an excellent example. A system to address concurrent jurisdiction and to govern possible disputes is merited. Secondly, the approach is desirable to temper prosecutorial zeal. Prosecutorial enthusiasm and the resources to act transnationally should not in themselves govern the extraterritorial application of criminal law. ${ }^{51}$ Thirdly, and perhaps most importantly, a proper law approach supports the rule of law in an international sense and brings clarity in the applicability of the criminal law. It does so by considering not only the interests of the state applying its criminal law, but also by taking into account additional factors including the interests of third states and the position of the accused.

There are several factors relevant in the consideration of the propriety of the application of criminal law, such as the place or places of the commission and effects (harm) of the act, the interests affected or possibly affected by the act, the nationality or residence of the accused and victims, the international desire to prosecute the act, the human rights of the accused and victims, the nature and whereabouts of evidence and witnesses, in addition to international comity. In a proper law analysis these factors must apply objectively to all states, not to any one state alone. Lending support to the inclusion of these factors is the English Director of Public Prosecution's (DPP's) Director's Guidance on the Handling of Cases where the Jurisdiction to Prosecute is shared with Prosecuting Authorities Overseas 2013. ${ }^{52}$ It provides that a prosecution should ordinarily be brought where most of the criminality or most of the loss or harm occurred. Other factors include the prospects of identifying and acquiring material relevant to the prosecution, the location of witnesses, the accused (and his connections with the UK) and co-defendants and the availability of

51 The prosecution of the NatWest Three by the authorities in Texas springs to mind here, see R (on the application of Bermingham) v Director of the SFO [2006] EWHC 200 (Admin), and Arnell, Scots Extradited, 4 Juridical Review (2008) pp. 241-271, at 241.

52 The Guidance is found at www.cps.gov.uk/publications/directors_guidance/director_s_ guidance_on_concurrent_jurisdiction.htm, (accessed 3 August 2016). 
extradition proceedings. ${ }^{53} \mathrm{~A}$ relevant international instrument in form and content is the Draft European Convention on Conflicts of Jurisdiction in Criminal Matters, produced by the Parliamentary Assembly of the Council of Europe in $1965 .{ }^{54}$ Although the Draft Convention remains a draft - it has not become a treaty ${ }^{55}$ - it is germane in identifying factors the drafting parties within the Council of Europe thought important at the time as well as in containing a scheme prioritising a number of those factors. The Draft Convention accords primacy to territory. Where there are multiple territorial connections in a single case article 3(3) provides a hierarchy, coming first is:

\footnotetext{
... the State on whose territory the constituent factor of the offence or attempted offence was committed or the constituent omission occurred; then, the State on whose territory an act of complicity was committed; lastly the State on whose territory the effect was produced.
}

Nationality is recognized as a basis secondary to territory. The Draft Convention accepts that states have the right to prosecute extraterritorial offences including those committed by aliens, if they constitute a danger to its external or internal safety, by article 2(2). This right, akin to protective jurisdiction, is prioritized. It exists independently of the rights of all other states, by article 7 .

Further authority indicating factors that may be included in a proper law approach is found in UK extradition and human rights law. UK extradition law has been amended to include a 'forum bar'. ${ }^{56}$ In essence it provides that an extradition may be barred where there is a substantial connection between the requested person and the UK. Considered in a forum bar analysis are the place where most of the harm occurred or was intended to occur, the interests of victims, any belief of a prosecutor that the UK is not the most

53 Two further sets of guidelines existing in the area are 'Eurojust - Making the Decision - Which Jurisdiction Should Prosecute' - Annex to Eurojust 2003 Annual Report, at www.eurojust. europa.eu/doclibrary/corporate/eurojust\%20Annual\%20Reports/Annual\%20Report\%202003/ Annual-Report-2003-EN.pdf, (accessed 3 August 2016), and the International Association of Prosecutors' - 'Making the Decision - Which Jurisdiction Should Prosecute', at www.iapassociation.org/IAP/media/IAP-Folder/IAP_Guidelines_Cases_of_Concurrent_Jurisdiction_ FINAL.pdf, (accessed 3 August 2016). Applying in the area, but not attempting to allocate jurisdiction are EU's Council Framework Decision 2009/948/JHA of 30 November 2009 on prevention and settlement of conflicts of exercise of jurisdiction in criminal proceedings, and the European Convention on the Transfer of Proceedings in Criminal Matters 1972, ETS 73, at www.coe.int/en/web/conventions/full-list/-/conventions/treaty/073, (accessed 3 August 2016).

$54 \mathrm{~S} /$ Jur X(16) 9,4 January 1965, cited at coe.archivalware.co.uk/awweb/pdfopener?smd=1\&md =1\&did=936207, (accessed 3 August 2016).

55 The Draft Convention was overtaken by the European Convention on the Transfer of Proceedings in Criminal Matters 1972, supra note 53, which did not follow the hierarchical approach taken by the Draft Convention.

56 See Arnell, The Forum Bar to Extradition, Scots Law Times (2013) pp. 169-171, at 169. 
appropriate jurisdiction, ${ }^{57}$ the availability of evidence, any delay that might arise, the desirability and practicability of all prosecutions taking place in one jurisdiction and the connections between the requested person and the UK. Whilst the forum bar does not seek to ascertain the most appropriate territory to try an individual (it is concerned with whether an extradition is in the interests of justice) it does involve considerations which are reasonably part of a proper law approach. Human rights jurisprudence also lends support and substance to a proper law approach. This has arisen particularly through arguments based upon the right to private and family life within extradition proceedings. Leading cases include Norris v Government of the US ${ }^{58}$ and R(HH) v Deputy Prosecutor of the Italian Republic, Genoa. ${ }^{59}$ Amongst the factors considered in these cases were connections between the accused, his spouse and children and the UK, the desire to address international criminality, the comity of nations and international legal obligation.

Applying a proper law approach to the UK's trial of Hamza's extraterritorial solicitation leads to the conclusion that it was proper and appropriate. There were various and weighty factors linking Hamza to the UK, not least territory and nationality. In addition, evidence of Hamza's speeches was present within the UK. Further and importantly, the connections between Hamza and third states are ill-defined and indistinct. Being tried for an inchoate crime, it is not clear whether anyone solicited did in fact commit murder - no one was prosecuted for such. It is also not possible to localise the solicitation to any one third country or territory. Victims, certainly particular victims in specific third states, did not lead to or condition Hamza's prosecution. Actual 'harm', as referred to in the UK's forum bar, was not at issue in his prosecution. Potential harm, admittedly, was. This took the form of murder by foreign nationals abroad. Clearly the states where such individuals were resident had an interest in applying their law to Hamza in that he encouraged harm to take place within their territory. Overall, though, it is reasonable to conclude that the English criminal law was properly applied to Hamza for the offence of solicitation to murder.

The propriety of the application of US law to Hamza is considerably less certain than the UK's. As seen, the US can be considered to have acted lawfully in regard to the hostage taking and training camp charges, largely on the basis of the passive personality and territorial bases of jurisdiction. The legality of its application of law to facilitating jihad in Afghanistan is moot. As to be expected, even stronger reservations can be expressed over the propriety of US action. This follows the proper law approach taking into account a wider set of circumstances, including interests that may conflict with those of the US. The reservations that exist stem from both underlying considerations and factors specific

\footnotetext{
57 It should be noted that the effect of a decision not to prosecute is a factor in favour of extradition, not against.

58 [2010] United Kingdom Supreme Court (UKSC) 9.

[2012] UKSC 25.
} 
to each circumstance. Generally, there are overarching or general points that militate against the propriety of US action. These include the facts that Hamza was a non-national and was never present in the US in pursuance of the crimes for which he was convicted. As noted, Hamza was in the UK throughout the period, and was a dual UK and Egyptian national. He was a UK resident together with his family, including his wife and eight children. Hamza's presence within the UK could be, and was, considered a threat to its security - a point which weighs in favour of the UK. ${ }^{60}$ Further, the evidence substantiating the charges against him was undoubtedly present in the UK - if only in electronic communication evidence. These underlying considerations lend weight to the conclusion that the US was not the appropriate jurisdiction to try Hamza for his acts.

A proper law analysis of Yemeni hostage taking charges builds upon the underlying considerations noted above. A first basic point is that Yemen is a state. Indeed, the effects and harm of the acts were clearly felt most strongly on Yemeni territory. The hostage taking was a blatant affront to Yemeni sovereignty and undoubtedly caused harm to the country, including the cost of undertaking the rescue and to its political and tourist reputation. A fact that further connects the incident to the Yemen is that the leader of the group who took the hostages and the person with which Hamza was in contact, Zein AlAbidine al-Mihdar, was a Yemeni national. In regard to the nationality of the victims, the UK suffered the greatest in terms of lives lost (three British nationals were killed during the rescue). An Australian national was also killed. Two of the hostages who were injured in the course of the gunfight to secure their release were Americans - with both testifying at Hamza's Manhattan trial. ${ }^{61}$ Canada had a lesser connection, with one of the hostages being a national who escaped physically unharmed. In sum, it appears clear that the two states with the greatest connection to the hostage taking were Yemen and the UK. That noted, a proper law analysis must include further general considerations including the desire and ability to act in light of a crime (including decisions not to act). This weighs against the Yemen and the UK. It will be discussed below.

The strongest case in favour of the propriety of US application of law exists in regard to the attempt to set up a terrorist training camp in Oregon. It, along with the UK, had a territorial connection to the act. The harm that would have resulted had the camp been created is without question connected most closely to the US. There were no victims of the act. Evidence of the acts of the three co-conspirators of Hamza's, Oussama Kassir, Haroon Aswat and Earnest Ujaama was found in the US. The nationality of those involved in the act was Swedish, American and British. Overall, though, it appears clear that no

60 The UK's concern over the threat faced by Hamza is evidenced in part by its attempts to deprive him of his UK nationality generally, and on the fact that the evidence put forward to do so was not made public on account of its national security relevance, see Abu Hamza v SSHD, supra note 12 .

${ }_{61}$ The presence of evidence and witnesses is a relevant consideration. The US was in a relatively strong position here. 
country would have been able to make a tenable argument that its law would have been more properly applied to the attempt to set up a terrorist training camp than the US.

A proper law of the crime analysis of the crimes of facilitating jihad is inconclusive. Territorially, Afghanistan, the UK, and perhaps Pakistan, are connected to the acts of Hamza and his co-conspirators. The US had no direct territorial connection. The participants included British and American nationals. The harm or possible future harm of the acts is impossible to localise. Such is the nature of international criminality that an attack could have taken place and/or affected any number of states. That noted, the US is not unreasonably considered more likely a terrorist target than most other states - certainly by Islamic fundamentalist groups. The best that can be said here is that the US, along with the UK and Afghanistan itself, were connected to the possible harm resulting from Hamza's acts. Evidence supporting the facilitating jihad allegations was likely spread amongst these three states. A proper law approach analysis of the facilitating jihad charges, then, appears to weigh in favour of the conclusion that the UK and Afghanistan were the most appropriate jurisdictions to take cognisance of the acts.

The final considerations that affect the proper law analysis of US action are of a general nature - they are the rule of law, prosecutorial enthusiasm, a common desire to address international criminality and human rights. Relating to the rule of law is the Hostages Convention and the UK-US Extradition Treaty 2003. The Convention inter alia obliges state parties to criminalise hostage taking, and to extradite or prosecute those accused of acts covered by it. In the absence of a UK prosecution or demands for Hamza's extradition by a state more closely connected, say Yemen or Australia, the US can be adjudged to be upholding the rule of law with the prosecution. This raises the effect, if any, of decisions to prosecute and not to prosecute in a proper law analysis. On the one hand these decisions should be immaterial to the proper law approach in that it should entail an objective weighing up of the various factors iterated above. On the other, it is not unreasonable to assume that underlying a prosecutorial decision is the consideration of a public interest test and therefore they merit weight. ${ }^{62}$ It is reasonable to conclude on this point that prosecutorial decisions are relevant, but are merely one of the factors that affect the propriety of an application of law and that they can be overcome in the presence of other factors.

The existence of international agreement to take action against inimical acts is a further general factor affecting the proper law analysis. Here an individual state's prosecutorial desire may be an incarnation of a common position. In such a case that state can be

62 Whilst the rules of double jeopardy and double criminality give effect to convictions and acquittals, the effect of decisions to prosecute per se, and perhaps more importantly decisions not to prosecute, is less clear. That noted, under the forum bar in UK extradition law a decision not to prosecute can be a factor taken into account in adjudging forum, and indeed is reviewable by a judge. 
seen to be acting on behalf of the global community. This point supports the US in regard to the hostage taking, but is ambivalent in regard to facilitating jihad. This is because there is no widespread consensus on the nature and definition of terrorism. The human rights of an accused and his family are also properly considered relevant in the proper law analysis. As seen, this was exhaustively considered in the ECtHR litigation in Ahmad $v U K$. Accordingly, it is not tenable to argue that Hamza's right to a private and family life was unjustifiably interfered with, or that he would be subjected to torture, inhuman or degrading treatment in the US so that it was not appropriate for his trial and possible imprisonment to take place there.

Applying the above considerations to the application of law by the US must lead to the conclusion that only in regard to the attempts to create a terrorist training camp in Oregon was US law properly applied. In the other two sets of circumstances the UK was more closely connected, followed by Yemen and Afghanistan. However, the UK chose not to act in regard to either the hostage taking or Hamza's activities relating to Afghanistan and Pakistan. This factor, in the light of the Hostages Convention, rule of law more generally, and the desire to prosecute serious international criminality, in a sense overcomes the impropriety of US action. Similar factors apply, albeit with less weight, in regard to the crimes of facilitating jihad. ${ }^{63}$ Overall, therefore, the proper law approach leads to the conclusion that the UK was the appropriate jurisdiction to try Hamza for the hostage taking in the Yemen and, perhaps, also for his actions in supporting the activities of Abassi and Ujaama in Afghanistan and Pakistan. As the UK chose not to do so, the balance then tilts towards the US in light of the general considerations noted above.

\section{Conclusion}

The trial by the UK of Hamza was clearly lawful under international law and appropriate. Both the territorial and nationality connections between Hamza and the UK lead to this conclusion. The legality and propriety of US action is less clear. On account of the generosity of the rules of criminal jurisdiction it is just perhaps possible to conclude that US action was lawful - the best that can be said is that it was of dubious legality. More clearly, it can be concluded that US action was in an objective and ideal sense inappropriate. Other states had considerably stronger connections to Hamza and his acts. What determined Hamza's fate at the end of the day was UK prosecutorial reluctance and American prosecutorial zeal, nothing else. In Hamza's case justice was done, albeit imperfectly. 
Hamza's case is salutary in exposing the complexities of modern transnational criminality and the inefficiencies and difficulties in the way of acting against it. The sophistication of the criminality stands in stark contrast to the relatively rudimentary rules governing criminal jurisdiction in international law. The development of international law by way of the introduction of a hierarchy of the bases of criminal jurisdiction and the introduction of a proper law of the crime approach would go some considerable way in addressing this dichotomy. Of course the development of the law in itself is not enough. What is also needed is a widespread commitment to open and co-operative enforcement and compliance. States must also come to appreciate the benefits that come from rules that limit and allocate criminal jurisdiction such that they will always act lawfully and will forego applying their law where it is not appropriate to do so. From an international perspective, however, the benefits are clear; adherence to the international rule of law, the maintenance of friendly relations between states and compliance with the human rights of accused persons. 